\title{
Mineral, protein, and energy supplementation in heifers in a native pampa biome pasture during winter
}

\section{Edgard Gonçalves Malaguez ${ }^{1}$, Thaís Lopes Gonçalves², Bibiana Bastos Giudice ${ }^{2}$, Ricardo Pedroso Oaigen², Deise Dalazen Castagnara ${ }^{2}$, Eduardo Bohrer de Azevedo ${ }^{3}$}

\author{
${ }^{1}$ Universidade Federal de Pelotas, Campus Capão do Leão, Capão do Leão, Rio Grande do Sul, Brasil. E-mail: \\ edgardgmalaguez@gmail.com
}

${ }^{2}$ Universidade Federal do Pampa, Campus Uruguaiana, Uruguaiana, Rio Grande do Sul, Brasil. E-mail: lopesg.thais@gmail.com, bibianagiudice@hotmail.com, rpoaigen@gmail.com,deisecastagnara@gmail.com,

${ }^{3}$ Universidade Federal do Pampa, Campus Itaqui, Itaqui, Rio Grande do Sul, Brasil. E-mail: ebazevedo@yahoo.com.br

Received: 12/04/2019; Accepted: 03/12/2019.

\section{ABSTRACT}

This study evaluated the effect of different supplements during winter on the performance of heifers in a native Pampa biome field using deferred grazing and evaluated the economic viability of each treatment. A total of 124 heifers from Brangus and Angus breeds, 18 months old, and with an average weight of $301.6 \mathrm{~kg}$ were included in this experiment. The treatments applied were: control with only native grassland, native grassland $+80 \mathrm{P}$ mineral salt treatment (MS), native grassland + protein salt treatment (PS), and native grassland + protein/energy salt treatment (PES). Besides the productive, botanical, and bromatological characteristics of the pasture, the average daily gain and the live weight gain per hectare were evaluated. The economic viability of the treatments was evaluated through partial budgeting. Weight loss was observed in all treatments. However, only the PES treatment differed from the others, with an average daily gain of $-0.046 \mathrm{~kg} \mathrm{dia}^{-1}$ ( $\mathrm{p}$ value $<0.005$ ). The MS treatment was the best regarding economic viability. Despite that, the smallest weight loss was observed in the PES treatment, which may be a determinant in the development and future performance of heifers. Despite the small net margin, this treatment did not incur additional costs to the system.

Keywords: animal performance, bioeconomic efficiency, rearing.

\section{Suplementação mineral, proteica e energética de novilhas em pastagem nativa do bioma pampa durante $o$ inverno}

\section{RESUMO}

Foi avaliado o efeito de diferentes suplementos sobre o desempenho de novilhas mantidas durante o inverno em campo nativo diferido do Bioma Pampa e suas respectivas viabilidades econômicas. Foram utilizadas 124 novilhas das raças Angus e Brangus, com 18 meses de idade e peso médio de 301,6 kg. Os tratamentos aplicados foram: controle (SS) somente com campo nativo; tratamento (SM) campo nativo + sal mineral 80P; tratamento (SP) campo nativo + sal proteinado e tratamento (SPE) campo nativo + sal protéico/energético. Foram avaliados o ganho médio diário (GMD; $\mathrm{kg}$ dia-1) e ganho de peso vivo (GPV; $\mathrm{kg} \mathrm{ha}^{-1}$ ), além de medidas produtivas, botânicas e bromatológicas da pastagem. A viabilidade econômica dos tratamentos foi avaliada por meio de orçamentação parcial. Em todos os tratamentos foram observadas perdas de peso, sendo que, apenas o tratamento SPE diferiu dos demais, com GMD observado de $-0,046 \mathrm{~kg}$ ( $\mathrm{p}<0,05)$. Quanto à viabilidade econômica, o tratamento SM foi superior, apesar disso, a menor perda de peso foi verificada no tratamento SPE, o que poderá ser determinante no desenvolvimento e desempenho futuro das novilhas. Apesar da margem estreita, este tratamento não gerou prejuízo ao sistema.

Palavras-chave: desempenho animal, eficiência bioeconômica, recria. 


\section{Introduction}

The intensification of livestock production systems has led to an increase in the area of cultivated pastures. Nevertheless, the native grassland formed by native species of the Pampa biome remains as the primary food source for herds in Rio Grande do Sul. In addition to its sustainable adaptability for livestock, the Pampa biome plays an important role regarding the conservation of water resources, pollinator availability, and genetic resource diversity (Pillar et al., 2009).

Most native forage species follow a warm-season cycle, i.e., they have the highest quantitative and qualitative production during spring and summer. In winter, there is a reduction in the quantity and quality of forage due to an increase in fiber content and a decrease in protein content. These characteristics limit the growth and performance of ruminal microorganisms, resulting in slow forage degradation, longer rumen retention time, and less nutrient consumption by animals (Van Soest, 1994). The seasonal production of the native grassland results in losses of up to $20 \%$ of the live weight, which is one of the main factors of the productive and economic inefficiency of the native grassland production systems (Fontoura Júnior et al., 2007; Knorr et al., 2005).

Among the available technologies, supplementation has been widely used in order to decrease the deleterious effects of this seasonal production and lowquality forage. Protein-energy supplementation has been used to maintain stocking rates during periods of low dry matter production, as well as a pasture management strategy to reduce degradation (Azevedo et al., 2008; Reis et al., 2009).

The most widely used commercial supplements have been protein, protein-energy, and mineral salts. Despite their widespread use, there is no consensus in the literature about the effects of supplementation and the superiority of one type of supplement over another. Furthermore, due to their high costs, some studies question the economic viability of supplements, especially the protein salt (Azevedo et al., 2008; Knorr et al., 2005; Pellegrini et al., 2014).

The objectives of this study were to evaluate the effect of supplementation during winter on the performance of heifers using deferred grazing in a native grass field and to evaluate the economic viability of each treatment.

\section{Material and Methods}

\subsection{Location and general characteristics of the area}

The study was carried out between May and August 2015 at Cabanha Umbu, which is located on BR 472 highway in Uruguaiana, in the southwest region of Rio Grande do Sul, Brazil. The farm is located in the Campanha physiographic region, at coordinates $29^{\circ} 59^{\prime} 15.5^{\prime \prime} \mathrm{S}$ and $57^{\circ} 12^{\prime} 24.4^{\prime \prime} \mathrm{W}$. The area allocated for the experiment encompasses approximately 89.8 ha of natural pasture of the Pampa biome. The area was subdivided into four paddocks with 21.4, 19.3, 24.6, and 24.5 ha, each containing a drinking fountain and covered feeders. Bromatological analyzes of the collected pasture were conducted at the Laboratory of Forage and Animal Nutrition of the Federal University of Pampa.

\subsection{Treatments}

The treatments tested the intensification of the supplements made available to the animals, which included: control treatment with only native grassland, native grassland $+80 \mathrm{P}$ mineral salt treatment (MS), native grassland + protein salt treatment (PS), and native grassland + protein/energy salt treatment (PES). The amount of supplement offered to the animals followed the manufacturer's recommendations, which were $100 \mathrm{~g} / \mathrm{animal} /$ day of mineral salt, $100 \mathrm{~g} / 100$ $\mathrm{kg} / \mathrm{animal} /$ day of protein salt, and $200 \mathrm{~g} / 100$ $\mathrm{kg} / \mathrm{animal} /$ day of protein/energy salt. The amount of supplement offered to each animal after the five-day adaptation period and after each monthly weighing is summarized in Table 1.

\subsection{Animals included and animal load}

A total of 124 heifers from the same herd, from Brangus and Angus breeds, 18 months old, and with an average weight of $301.6 \mathrm{~kg}$ were included in this experiment. The supplementation was carried out for 112 days. The animals were randomly selected and evenly distributed over the four paddocks.

Table 1. Amount of supplement offered to animals after the adaptation and weighing periods.

\begin{tabular}{lccc}
\hline \multirow{2}{*}{ Period } & \multicolumn{2}{c}{ Treatments } \\
\cline { 2 - 4 } & $80 \mathrm{P}$ mineral salt & Protein salt & Protein/energy salt \\
\hline Adaptation Period & $100 \mathrm{~g} / \mathrm{animal} / \mathrm{day}$ & $150 \mathrm{~g} / \mathrm{animal} / \mathrm{day}$ & $300 \mathrm{~g} / \mathrm{animal} / \mathrm{day}$ \\
After $1^{\text {st }}$ weighing & $100 \mathrm{~g} / \mathrm{animal} / \mathrm{day}$ & $310 \mathrm{~g} / \mathrm{animal} / \mathrm{day}$ & $620 \mathrm{~g} / \mathrm{animal} / \mathrm{day}$ \\
After $2^{\text {nd }}$ weighing & $100 \mathrm{~g} / \mathrm{animal} / \mathrm{day}$ & $293 \mathrm{~g} / \mathrm{animal} / \mathrm{day}$ & $597 \mathrm{~g} / \mathrm{animal} / \mathrm{day}$ \\
After $3^{\text {rd }}$ weighing & $100 \mathrm{~g} / \mathrm{animal} / \mathrm{day}$ & $283 \mathrm{~g} / \mathrm{animal} / \mathrm{day}$ & $582 \mathrm{~g} / \mathrm{animal} / \mathrm{day}$ \\
After $4^{\text {th }}$ weighing & $100 \mathrm{~g} / \mathrm{animal} / \mathrm{day}$ & $277 \mathrm{~g} / \mathrm{animal} / \mathrm{day}$ & $589 \mathrm{~g} / \mathrm{animal} / \mathrm{day}$ \\
\hline
\end{tabular}


Heifers were rotated between paddocks every 28 days to reduce the possible effects of the paddocks on the treatments, which could include the location of water, shade, and topographical relief. Additionally, the distribution of treatments was kept the same in groups of animals when there was a paddock change. In addition to the 31 test heifers in each paddock, additional regulating animals were added or removed in order to constrain the amount of forage to $12 \%$.

\subsection{Parameters evaluated}

To characterize the forage of the area, quantitative and qualitative measurements were made every 28 days. To identify the existing vegetation in the area, the botanical composition was analyzed walking through the field. The following species were identified: caninha grass (Andropogon lateralis Nees), zarzabacoa comun (Desmodium incanum), dixie ticktrefoil (Desmodium tortuosum), broadleaf woodsorrel (Oxalis latifolia kunth), Brazilian calla-lily (Richarday brasiliensis), mio-mio (Baccharis coridifolia), scutch grass (Cynodon dactylon), horseweed (Conyza canadensis), shameplant (Mimosa pudica), and Paddy's lucerne (Sida rhombifolia). The pasture showed an area of high infestation of tough lovegrass (Eragrostis plana Nees). The predominant species were tough lovegrass, caninha grass, and dixie ticktrefoil.

To obtain knowledge of the forage mass, random samples were collected in five different locations within each paddock, using a square of $0.25 \mathrm{~m}^{2}$. The samples were weighed and dried in an oven with forced air ventilation for 72 hours at $55^{\circ} \mathrm{C}$. The green mass and the dry mass were then obtained by calculating the dry matter yield from the sub-samples $\left(\mathrm{g} / 0.25 \mathrm{~m}^{2}\right.$ or $\mathrm{kg} / 0.25$ $\mathrm{m}^{2}$ ). The yield was expressed in $\mathrm{kg}$ of dry matter/ha. Before drying, the samples were classified into green mass, dead mass, inflorescence, and legumes.

The qualitative evaluation of pastures was carried out by collecting pasture samples based on the cattle's selection habits while grazing (Johnson, 1978). The samples were analyzed in the laboratory for content; amount of dry matter (DM) after drying at $105^{\circ} \mathrm{C}$ for 12 hours; organic matter $(\mathrm{OM})$ and mineral matter (MM) by burning in a muffle furnace at $550{ }^{\circ} \mathrm{C}$; crude protein (CP) by the Kjeldahl method as described by Silva and Queiroz (2002); neutral detergent fiber (NDF) and acid detergent fiber (ADF) according to Van Soest and Robertson (1985), corrected for ashes and lignin. The values of total digestible nutrients (TDN) were estimated by the equation $\mathrm{TDN}=87.84-(0.7 *$ $\%$ ADF), according to Teixeira (1998).

The parameters related to animal production were calculated monthly, where the average daily gain (ADG; $\mathrm{kg}$ day $^{-1}$ ) corresponded to the individual animal weight difference from the beginning to the end of each period divided by the number of days in the period. To obtain the live weight gain in $\mathrm{kg} \mathrm{ha}^{-1}$, ADG was multiplied by the number of animals per hectare and the number of days in each period.

In order to analyze the economic viability and compare the treatments, partial budgeting was used, according to the method applied by Costa et al. (1982). The economics of the different treatments were assessed using the net margin and the rate of return per invested Brazilian real (BRL). The net margin was defined as the additional profit minus the cost of the treatment, and the rate of return was defined as the net margin divided by the treatment cost.

The value obtained by the weight gain of the animals was considered the profit, with the additional profit being the gain obtained in a treatment when compared to the control group. Costs, in addition to expenses with supplements, considered the BRL interest rate of $0.5 \%$ per month without taking into account the inflation.

\subsection{Experimental design and statistical analysis}

The experimental design was completely randomized with four treatments, each animal being an experimental unit. Data were submitted to analysis of variance, and the means were compared by the Tukey test considering $\mathrm{p}$ values $<0.05$ to be statistically significant. For bromatological analysis based on repeated measures over time, where each period was 28 days, regression analysis was adopted. The general statistical model for the analysis of the variables studied was represented by $Y_{i j}=\mu+T_{i}+E_{j}+(T * E)_{i j}+\Sigma_{i j}$, in which $Y_{i j}=$ dependent variables, $\mu=$ constant inherent in all observations, $T_{i}=$ effect of treatments, $E_{j}=$ effect of the seasons, $(\mathrm{T} * \mathrm{E})_{\mathrm{ij}}=$ interaction between treatments and seasons, and $\Sigma_{\mathrm{ij}}=$ residual experimental error (error B).

\section{Results and Discussion}

Forage production rates are affected by many factors, including climatic effects. According to Zhu et al. (2008), forage production varies mainly in response to changes in physical variables, including solar radiation, temperature, and water availability, which can be considered alone or in combination. During our experimental period, high average temperatures and total precipitation were observed. The average maximum temperature was $22.07{ }^{\circ} \mathrm{C}$, and the lowest average minimum temperature was recorded in July, and it was $9.81{ }^{\circ} \mathrm{C}$. The average total precipitation was $93.7 \mathrm{~mm}$ distributed unevenly throughout the experiment, with a maximum of $146.1 \mathrm{~mm}$ in August and a minimum of $52 \mathrm{~mm}$ in June (Table 2).

It was assumed that there was no water deficiency and that temperatures did not interfere with the 
development of winter forages during the experimental period. This explains the climatic growth rate of legumes and inflorescence, which had a linear increase during the experiment of $12.96 \mathrm{~kg} / \mathrm{ha}$ and $50.54 \mathrm{~kg} / \mathrm{ha}$, respectively (Figure 1). Legumes are susceptible to high temperatures and reasonably tolerant to frost.

The decrease in green and dead matter, as shown in Figure 1, can be explained by (a) the reduction of the photoperiod during the winter, which results in a decrease in the number of leaves; and (b) a reduction in the growth rates of the pasture due to the decrease in temperature, which causes a reduction in animal consumption. This consumption of dry matter is directly related to the availability and quality of forage (Silva et al., 2009).

The forage mass decreased from $5115 \mathrm{~kg} \mathrm{ha}^{-1}$ in May to $4164 \mathrm{~kg} \mathrm{ha}^{-1}$ in August (Figure 2). These values were higher than those found by Pellegrini et al. (2014) during winter, who observed an average of $3300 \mathrm{~kg} \mathrm{ha}^{-1}$. However, the average forage mass during our experimental period was $4445 \mathrm{~kg} \mathrm{ha}^{-1}$, which corresponds to a forage allowance of $0.059 \mathrm{~kg}$ of body weight, which according to Barbosa et al. (2006) is below the range of body weight $(0.070-0.110 \mathrm{~kg})$ necessary to obtain high average daily gain without affecting too much of the gain per area.

The consumption of dry matter of forage plants is related to its percentage of NDF, while the digestibility of dry matter is related to the ADF and mainly the participation of lignin (Moura et al., 2011). The NDF content decreased linearly during the study by $1.03 \mathrm{~kg}$ per day, which can be justified by the increase in legumes (Table 3). The average NDF observed during the period was $755.65 \mathrm{~g} / \mathrm{kg}$ of DM, which was higher than the $663 \mathrm{~g} / \mathrm{kg}$ of DM found by Pellegrini et al. (2016). When the NDF values are greater than 550-600 $\mathrm{g} / \mathrm{kg}$, consumption decreases due to the filling effect (Mertens, 2003). This effect is due to physiological factors, including tension receptors located in the rumen wall. When these receptors are stimulated, they inhibit voluntary consumption, acting as a metabolic control mechanism (Costa et al., 2015). In our study, the infestation of tough lovegrass, which has characteristics of coarse pasture, explains the lower consumption.

Table 2. Monthly meteorological observations during the experimental period.

\begin{tabular}{lccc}
\hline \multirow{2}{*}{ Month } & Total Precipitation $(\mathbf{m m})$ & \multicolumn{2}{c}{ Average temperature $\left({ }^{\circ} \mathrm{C}\right)$} \\
\cline { 3 - 4 } & 100.60 & 23.57 & Minimum \\
\hline May & 52.01 & 21.18 & 13.08 \\
June & 76.01 & 19.15 & 9.161 \\
July & 146.10 & 24.39 & 14.28 \\
August & 93.70 & 22.07 & 12.08 \\
\hline Average
\end{tabular}

Source: INMET

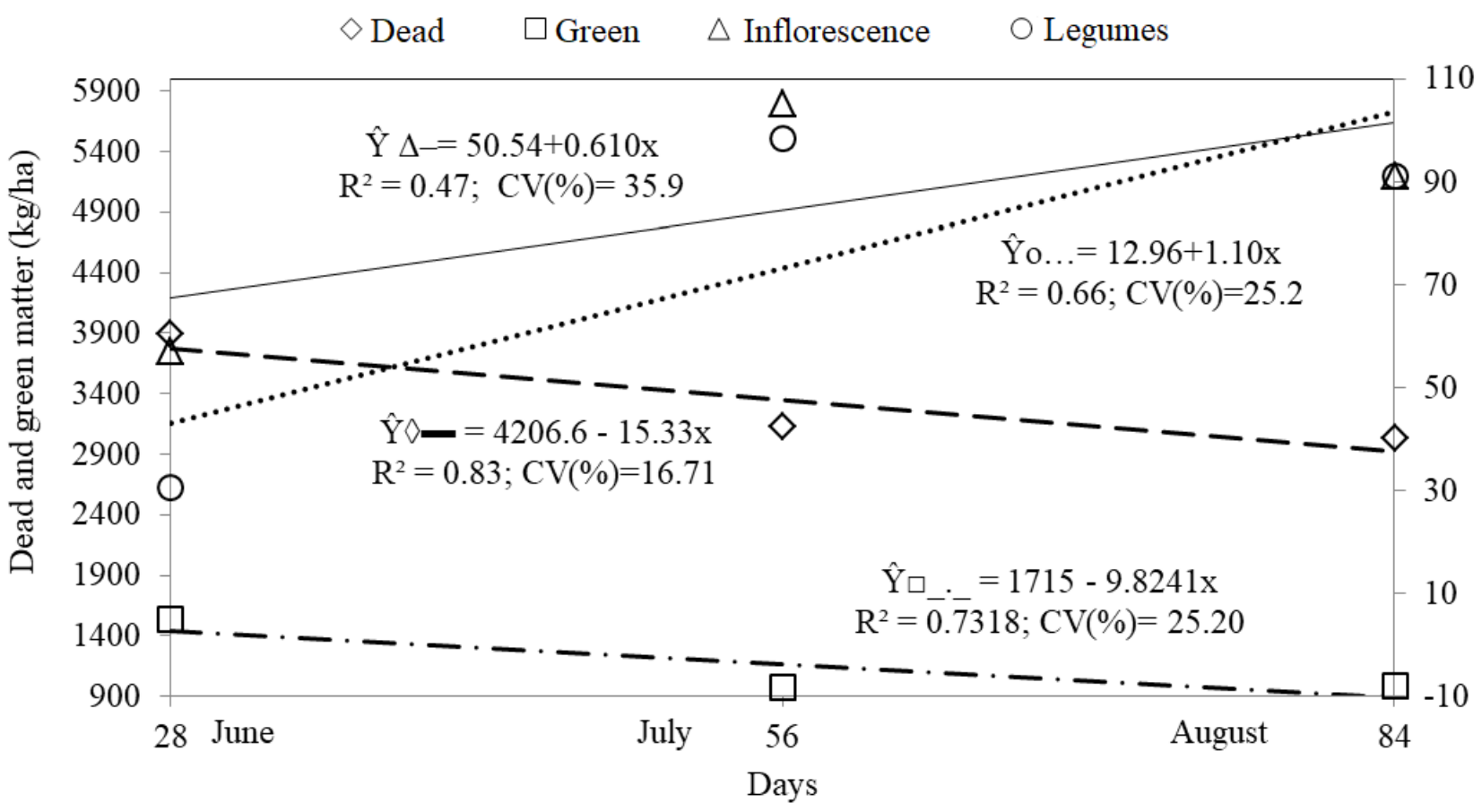

Figure 1. Deposition of dead matter, green matter, inflorescence, and legume during the experimental period. 


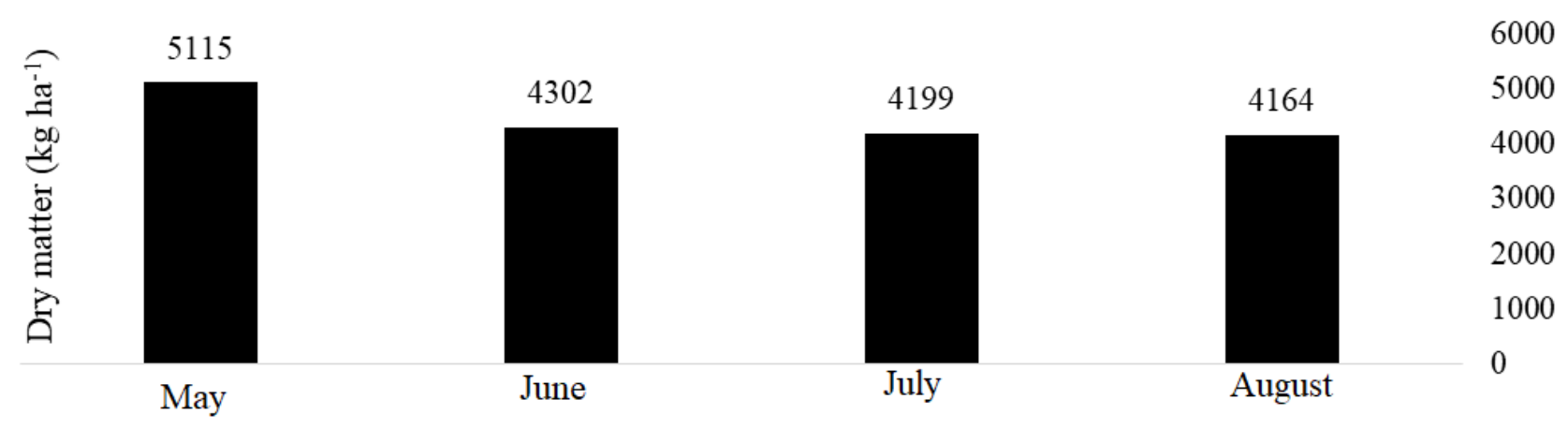

Figure 2. Mass of dry matter during the experimental period.

Table 3. Bromatological evaluation of the native grassland in a farm in Uruguaiana, Rio Grande do Sul, during the fall and winter of 2015.

\begin{tabular}{|c|c|c|c|c|c|c|c|c|}
\hline \multicolumn{5}{|c|}{ Evaluation day (month) } & \multirow[b]{2}{*}{ Regression equation } & \multirow[b]{2}{*}{$P$ value } & \multirow[b]{2}{*}{$\mathrm{R}^{2}$} & \multirow[b]{2}{*}{$\mathrm{CV}(\%)$} \\
\hline & $\begin{array}{c}0 \\
\text { (May) }\end{array}$ & $\begin{array}{c}28 \\
\text { (June) }\end{array}$ & $\begin{array}{c}56 \\
\text { (July) }\end{array}$ & $\begin{array}{c}84 \\
\text { (August) }\end{array}$ & & & & \\
\hline MM & 69.24 & 85.06 & 100.34 & 73.75 & $Y=74.89+2.87 x$ & 0.004 & 0.85 & 14.45 \\
\hline $\mathrm{OM}$ & 930.76 & 914.94 & 899.66 & 926.25 & $Y=506.06-1.38 x$ & 0.019 & 0.62 & 13.58 \\
\hline NDF & 751.94 & 732.08 & 697.57 & 666.45 & $Y=755.65-1.03 x$ & 0.012 & 0.99 & 5.89 \\
\hline $\mathrm{ADF}$ & 417.30 & 429.31 & 410.45 & 346.36 & $Y=435.60-0.827 x$ & 0.049 & 0.64 & 12.15 \\
\hline LIG & 143.70 & 101.01 & 204.55 & 113.99 & $Y=137.93+1.71 x$ & 0.001 & 0.52 & 21.48 \\
\hline $\mathrm{CP}$ & 46.97 & 54.07 & 64.37 & 73.73 & $Y=46.196+0.323 x$ & 0.004 & 0.99 & 17.78 \\
\hline TDN & 586.29 & 577.88 & 591.08 & 635.95 & $Y=573.48+0.58 x$ & 0.048 & 0.65 & 5.70 \\
\hline
\end{tabular}

MM, mineral matter; OM, organic matter; NDF, neutral detergent fiber; ADF, acid detergent fiber; LIG, lignin; CP, crude protein; TDN, total digestible nutrients; $\mathrm{CV}$, coefficient of variation; $\mathrm{R}^{2}$, coefficient of determination. The statistical model used was a regression with analysis of variance considering a significant level of 0.05 . P value: $\mathrm{p}$ value for the tested regression model.

The ADF content behaved similarly to that of NDF, with a linear reduction of $0.827 \mathrm{~kg}$ of $\mathrm{DM}$, which can be explained by the increase in the proportion of legumes in the field. However, lignin had a linear increase of $1.71 \mathrm{~kg}$ of DM over the period of the study. Although it is not a fibrous carbohydrate, lignin adheres to the cell wall and is quantified together with NDF, being one of the main components responsible for the reduction in fiber digestibility. Foods high in lignin show a reduction in NDF digestibility due to the effect that lignin exerts on ruminal microorganisms, including the toxicity of phenolic compounds and the physical barrier formed, which prevents the attack of microorganisms (Van Soest, 1994).

The CP had a linear increase of $0.323 \mathrm{~g} / \mathrm{kg}$ of DM, with $4.7 \%$ of DM in May and $7.4 \%$ of DM in the last month of the experiment, i.e., August. These values were within the range found by Santos et al. (2013), which varied between $4.5 \%$ and $10.7 \%$ of DM among the studied species. Their study was carried out from September 2007 to May 2008, a period in which the native grassland had excellent yields. Another important factor that contributed to the $\mathrm{CP}$ increase was the increase in the presence of legumes during our experiment. According to Taiz and Zeiger (2009), legumes accumulate a greater amount of nitrogen and proteins due to the constituents of their tissues. However, the minimum CP level of $0.70 \mathrm{~g} / \mathrm{kg}$ recommended for ruminal functioning (Van Soest, 1994) was only observed in August.

A significant difference ( $\mathrm{p}$ value $<0.05$ ) in average daily gain was observed between treatments. Heifers that received protein/energy mineral salt had less weight reduction $(-0.046 \mathrm{~g} / \mathrm{kg})$ when compared to the other groups. The weight reduction in the control, mineral salt, and protein mineral salt groups was $-0.225,-0.165$, and $-0.225 \mathrm{~kg}$, respectively (Table 4). However, animals supplemented with mineral salt and protein mineral salt showed similar results as found by Knorr et al. (2005). They evaluated the performance of supplementation of steers in deferred grazing and, unlike our study, found positive gains. They also observed no differences between the mineral salt and the protein salt formulated with urea and amireia, which is an extrusion product of starch and urea.

Azevedo et al. (2010) observed the inefficiency of urea in improving forage digestibility. According to the authors, these results may be linked to the animal's ability to efficiently use the nitrogen that circulates in the organism. Additionally, the intrinsic characteristics of the forage cell wall have degradation limitations that are not affected by supplementation. 
The differences in ADG were reflected in the average total gain and the live weight gain per hectare. The PES treatment showed significantly reduced deficits for both average total gain $\left(-5.10 \mathrm{~kg}_{\text {animal }}{ }^{-1}\right)$ and live weight gain per hectare $\left(-7.11 \mathrm{~kg} \mathrm{ha}^{-1}\right)$ when compared to the other three treatments. Despite the animal performance being negative, and the quality of pasture being low, the variables evaluated were influenced by the treatments.

It is believed that the absence of positive weight gain of heifers due to supplementation is related to lowquality pasture and high infestation of tough lovegrass. Carlotto et al. (2010), when researching the influence of protein and mineral supplementation on the ingestive behavior of primiparous cows in a native pasture dominated by tough lovegrass, found that supplementation had no effect on grazing, rumination, idleness, and other activities. The dominance of tough lovegrass and the uniformity of the forage mass during the experiment period caused the animals to spend most of the day in grazing activity due to the high fiber content and the difficulty of digesting this material. According to Azevedo et al. (2008), the digestive response regarding protein supplementation depends on the characteristics of the forage used, the most important being the amount of degradable protein in the rumen present in the forage and the digestion potential of the cell wall. The effect of protein supplementation was also assessed by Paris et al. (2013), in Tifton-85 pasture during the fall and winter months. In their study, animal performance was not affected by protein supplementation when compared to mineral supplementation.

From an economic point of view (Table 5), the smaller weight loss in the PES and MS groups resulted in a higher net margin and rate of return for these groups. Despite the greatest productivity observed in the PES treatment, its high cost was responsible for the less favorable net margin compared to the MS treatment.

Supplementation with protein mineral salt resulted in the worst economic performance, with weight losses similar to non-supplementation. Therefore, this treatment does not justify the investment since for each BRL invested per animal, 1.04 BRL was lost. Our results differ from Knorr et al. (2005), who observed that supplementation with mineral salt obtained negative economic results and worse animal performance, while protein salt supplementation presented the best economic and animal performance results. However, our results agree with Moreira et al. (2003), who showed that protein salt during the winter did not improve animal performance compared to mineral salt.

Table 4. Mean initial live weight, average daily gain, final live weight, average total gain, live weight gain per hectare, and supplement consumption of heifers kept in the native grassland.

\begin{tabular}{lcccc}
\hline \multirow{2}{*}{ Variable } & \multicolumn{3}{c}{ Treatments } \\
\cline { 2 - 5 } & Control & MS & PS & PES \\
\hline Initial live weight $(\mathrm{kg})$ & 300.68 & 300.48 & 301.68 & 300.68 \\
Average daily gain $\left(\mathrm{kg} \mathrm{animal}^{-1} \mathrm{day}^{-1}\right)$ & $-0.225^{\mathrm{b}}$ & $-0.165^{\mathrm{b}}$ & $-0.225^{\mathrm{b}}$ & $-0.046^{\mathrm{a}}$ \\
Final live weight $(\mathrm{kg})$ & 266.39 & 281.97 & 275.97 & 287.03 \\
Average total gain $\left(\mathrm{kg} \mathrm{animal}{ }^{-1}\right)$ & $-25.16^{\mathrm{b}}$ & $-18.52^{\mathrm{b}}$ & $-25.71^{\mathrm{b}}$ & $-5.10^{\mathrm{a}}$ \\
Live weight gain per ha $\left(\mathrm{kg}^{\mathrm{b}}\right.$ & $-35.10^{\mathrm{b}}$ & $-25.83^{\mathrm{b}}$ & $-35.20^{\mathrm{b}}$ & $-7.11^{\mathrm{a}}$ \\
Supplement consumption $\left(\mathrm{kg} \mathrm{day}^{-1}\right)$ & - & 0.100 & 0.290 & 0.584 \\
\hline
\end{tabular}

Control, without supplementation; MS, mineral supplementation; PS, protein supplementation; PES, protein-energy supplementation. Superscripts with the same letters on the same line indicate no significant differences in the means between treatments, according to the Tukey test considering a significance level of 5\%.

Table 5. Analysis of the economic viability of three supplementation treatments in the rearing of heifers in native grasslands using the partial budgeting technique.

\begin{tabular}{lcccc}
\hline & Control & MS & PS & PES \\
\hline Profit (BRL) & -132.10 & -97.21 & -134.98 & -26.76 \\
Additional profit (BRL) & & 34.89 & -2.88 & 105.34 \\
Treatment cost (BRL) & & 24.22 & 70.28 & 104.14 \\
Net margin (BRL) & & 10.66 & -73.16 & 1.20 \\
Rate of return (BRL) & & 0.44 & -1.04 & 0.01
\end{tabular}

BRL, Brazilian real; Control, without supplementation; MS, mineral supplementation; PS, protein supplementation; PES, proteinenergy supplementation. 


\section{Conclusions}

Supplementation with mineral, protein, or proteinenergy did not prevent animals from losing weight during the evaluated period. Despite this, the use of a protein-energy supplement made it possible to reduce the heifers' weight loss, indicating its suitability as a nutritional strategy for animals in low-quality pastures.

From an economic point of view, the use of mineral salt showed a better rate of return during the studied period. The lower weight loss promoted by the proteinenergy supplement may be a decisive factor in the development and future performance of heifers, suggesting that further studies should be conducted considering a holistic view of the production system.

\section{Bibliographic References}

Azevedo, E.B., Patiño, H.O., Silveira, A.L.F., Lopes, J., Brüning, G., Kozloski, G.V., 2008. Incorporação de uréia encapsulada em suplementos protéicos fornecidos para novilhos alimentados com feno de baixa qualidade. Ciência Rural, 38(5), 1381-1387.

Azevedo, E.B., Patiño, H.O., Silveira, A.L.F., Lopes, J., Norberg, J.L., Bruning, G., 2010. Suplementação nitrogenada com ureia comum ou encapsulada sobre parâmetros ruminais de novilhos alimentados com feno de baixa qualidade. Ciência Rural, 40(3), 622-627.

Barbosa, M.A.F., Junior, D.N., Cecato, U., 2006. Dinâmica da pastagem e desempenho de novilhos em pastagem de capimtanzânia sob diferentes ofertas de forragem. Revista Brasileira de Zootecnia, 35(4), 1594-1600.

Carlotto, S.B., Medeiros, R.B., Pellegrini, C.B., Garcia, R.P.A., Lisboa, C.A.V., Saibro, J.C., 2010. Comportamento ingestivo diurno de vacas primíparas em pastagem nativa dominada por capim-annoni-2 com suplementação proteica e mineral em diversas estações climáticas. Revista Brasileira de Zootecnia, 39(3), 454-461.

Costa, F.P., Souza, J.C., Gomes, R.F.C., Silva, J.M., Euclides, V.P.B., 1982. Avaliação econômica de alternativas de suplementação mineral. Pesquisa Agropecuária Brasileira, 17(7), 1083-1088.

Costa, N.L., Monteiro, A.L.G., Silva, A.L.P., Moraes, A., Giostri, A.F., Stivari, T.S.S., Baldissera, T.C., Pin, E.A., 2015. Considerações sobre a degradação da fibra em forragens tropicais associada com suplementos energéticos ou nitrogenados. Archivos de Zootecnia, 64(R), 31-41.

Fontoura Júnior, J.A.S., Carvalho, P.C.F., Nabinger, C., Silva, J.L.S., Pinto, C.E., Crancio, L.A., 2007. Produção animal em pastagem nativa submetida ao controle de plantas indesejáveis e a intensidades de pastejo. Ciência Rural, 37(1), 247-252.

Johnson, A.D., 1978. Sample preparation and chemical analysis of vegetation, in: Mannetje, L.T., (Ed.), Measurement of grassland vegetation and animal production. Aberystwyth, Commonwealth Agricultural Bureaux, p. 96-102.
Knorr, M., Patino, H.O., Silveira, A.L.F., Muhlbach, P.R.F., Mallmann, G.M., Medeiros, F.S., 2005. Desempenho de novilhos suplementados com sais proteinados em pastagem nativa. Pesquisa Agropecuária brasileira, 40(8), 783-788.

Mertens, D.R., 2003. Challenges in measuring insoluble dietary fiber. Journal of Animal Science, 81(12), 3233-3249.

Moreira, F.B., Prado, I.N., Cecato, U., Souza, N.E., Iwayama, P.T., 2003. Suplementação com sal mineral proteinado para bovinos de corte mantidos em pastagem de estrela roxa no final do verão. Acta Scientiarum Animal Sciences, 25(1), 185 191.

Moura, R.L, Nascimento, M.P.S.C.B., Rodrigues, M.M., Oliveira, M.E., Lopes, J.B., 2011. Razão folha/haste e composição bromatológica da rebrota de estilosantes Campo Grande em cinco idades de corte. Acta Scientiarum Animal Sciences, 33(3), 249-254

Paris, W., Marchesan, R., Prohmann, P.E.F., Menezes, L.F.G., Zanotti, J., Hartmann, D.V., 2013. Utilização de uréia de liberação lenta em sal mineral na suplementação de bovinos de corte em pastagem de Tifton-85. Semina: Ciências Agrárias, 34(1), 409-418

Pellegrini, C.B., Garcia, R.P.A., Medeiros, R.B., Carlotto, S.B., Lisboa, C.A.V., Netto, C.G.A.M., 2014. Retorno econômico de vacas primíparas suplementadas em pastagem nativa dominada por Eragrostis planna Nees. Revista Brasileira de Ciências Agrárias (Agrária), 9(4), 619-625.

Pellegrini, C.B., Medeiros, R.B., Carlotto, S.B., Garcia, R.P.A., Lisboa, C.V., Bruning, G., 2016. Valor nutritivo de uma pastagem nativa dominada por eragrostis plana nees e sua relação com o perfil metabólico de vacas primíparas suplementadas da gestação ao pós-parto. Ciência Animal Brasileira, 17(2), 154-163.

Pillar, V.P., Muller, S.C., Castilhos, Z.M.S., Jacques, A.V.A., 2009. Campos Sulinos - conservação e uso sustentável da biodiversidade, primeira ed. Ministério do Meio Ambiente, Brasília.

Reis, R.A., Ruggieri, A.C., Casagrande, D.R., Pascoa, A.G., 2009. Suplementação da dieta de bovinos de corte como estratégia do manejo das pastagens. Revista Brasileira de Zootecnia, 38(spe), 147-159.

Santos, A.B., Quadros, F.L.F., Rossi, G.E., Pereira, L.P., Kuinchtner, B.C., Carvalho, R.M.R., 2013. Valor nutritivo de gramíneas nativas do Rio Grande do Sul/Brasil, classificadas segundo uma tipologia funcional, sob queima e pastejo. Ciência Rural, 43(2), 342-347.

Silva, D.J., Queiroz, A.C., 2002. Análises de alimentos métodos químicos e biológicos, terceira ed. Editora UFV, Viçosa.

Silva, F.F., Sá, J.F., Schio, A.R., Ítavo, L.C.V., Silva, R.R., Mateus, R.G., 2009. Suplementação a pasto: disponibilidade e qualidade $\mathrm{x}$ níveis de suplementação $\mathrm{x}$ desempenho. Revista Brasileira de Zootecnia, 38(spe), 371-389.

Taiz, L., Zeiger, E., 2009. Fisiologia vegetal, quarta ed. Artmed, Porto Alegre. 
Teixeira, A.S., 1998. Alimentos e alimentação dos animais, primeira ed. Universidade Federal de Lavras, Lavras.

Van Soest, P.J., 1994. Nutritional ecology of the ruminant, second ed. Cornell University Press, Ithaca.
Van Soest, P.J., Robertson, J.B., 1985. Analysis of forages and fibrous foods, first ed. Cornell University, Ithaca.

Zhu, X.G., Long, S.P., Ort, D.R., 2008. What is the maximum efficiency with which photosynthesis can convert solar energy into biomass? Current Opinion in Biotechnology, 19(2), 153159. 